\title{
Effect on Crude Fibre, Iron and Calcium Content of Multi Flour Noodles during Storage
}

\author{
Sunil*, Neelesh Chauhan, Vipul Chaudhary, Vaishali, Balwant Singh and \\ Vikrant Kumar \\ Department of Agricultural Engineering, Sardar Vallabhbhai Patel University of Agriculture \\ and Technology, Modipuram, Meerut (U.P.) India \\ *Corresponding author
}

A B S T R A C T

\section{Keywords \\ Multi- flour, \\ Noodles and High density polyethylene}

\section{Article Info}

Accepted:

10 March 2019 Available Online: 10 April 2019
Experiments were conducted to development, quality evaluation and storage stability of multi- flour noodles made from wheat flour, soya bean flour, carrot powder, mushroom flour and apple pomace powder. The noodles were formulated by taking different proportion of multi-flours in the ratio of $\left(\mathrm{T}_{100}\right)$ 100:0:0:0:0, $\left(\mathrm{T}_{90}\right)$ 90:2.5:2.5:2.5:2.5, $\left(\mathrm{T}_{80}\right)$ 80:5.0:5.0:5.0:5.0, $\quad\left(\mathrm{T}_{70}\right) \quad$ 70:7.5:7.5:7.5:7.5, $\quad\left(\mathrm{T}_{60}\right) \quad 60: 10: 10: 10: 10$ and $\left(\mathrm{T}_{50}\right)$ $50: 12.5: 12.5: 12.5: 12.5$ respectively. Wheat flour of the ratio of 100:0:0:0:0 was considered as control. All the samples were packed in high density polyethylene (HDPE) and stored at room temperature from 0 to 60 days for quality evaluation. After preparation of noodles various physico-chemical properties were determined, i.e., crude fiber, iron content and calcium content.

\section{Introduction}

The main objective of the food industry is to obtain safe food without contaminating elements which can produce diseases or be harmful to human beings. In addition, food must have beneficial physical and psychological effects on people.

The consumer must feel at ease at the time of eating knowing that the food is not only palatable but also healthy (Acuna, 2011). In this era of global industrialization and advancement of technologies, the life style of the people has changed a lot. In this changing life style, the demand for ready to eat foods like extruded foods has raised considerably.

This is due to change in perception, economic consideration, westernization, urbanization, busy life, increased women employment and increased per capita income. Among ready to eat foods, noodles form an important part of Indian dietary. These products are rich in starch, fat and energy but depleted in fiber. Various epidemiological studies have shown 
that the diet lacking in fiber may be the cause of various gastrointestinal and cardiovascular diseases (Kumari et al., 2007). Noodles are an important part in the diet of many Asians.

It is believed that noodles originated in China as early as 5000 B.C., then spread to other Asian countries and World. Many varieties of noodles are produced with different composition, method of preparation and presentation depending on regional preferences (Edwards et al., 1996). Noodles are one of the convenient food prepared and have been considered to symbolize long life and good luck in Asian culture (Sowbhagya and Ali, 1994). Wheat based noodles are nutritious, store well and are easy to prepare. Indofood is the largest instant noodles manufacturer in the world, with installed capacities of approximately 13 billion packs per annum (Fabiosa, 2006).

Extruded products are mostly made from cereal flour or starches and tend to be low in protein with low biological value. The incorporation of enriched fiber flours with high amount of antioxidants is a way to improve the nutritional value of extruded products (Ainsworth et al., 2007, Stojceska et al., 2008a, Stojceska et al., 2008b).

\section{Materials and Methods}

The experiments were conducted to develop multi-flours noodles and its physico-chemical quality during storage. Multi- flour comprising wheat flour, soya bean flour, carrot powder, mushroom flour and apple pomace powder were used for the present study.

The noodles were formulated using various proportions of flours and other ingredients. All the experiments were conducted in food analysis laboratory and bakery laboratory in the Department of Agricultural Engineering.

\section{Development of noodles}

Wheat flour was mixed with soya bean flour, carrot powder, mushroom flour, and apple pomace powder and noodles were prepared according to the following treatments using the recipe described below:

\section{Treatments}

$\mathrm{T}_{1}$ - Noodles made by $100 \%$ wheat flour

$\mathrm{T}_{2}-270 \mathrm{~g}$ wheat flour, $7.5 \mathrm{~g}$ soya bean flour, $7.5 \mathrm{~g}$ carrot powder, $7.5 \mathrm{~g}$ mushroom flour and $7.5 \mathrm{~g}$ apple pomace powder.

$\mathrm{T}_{3}-240 \mathrm{~g}$ wheat flour, $15 \mathrm{~g}$ soya bean flour, $15 \mathrm{~g}$ carrot powder, $15 \mathrm{~g}$ mushroom flour and $15 \mathrm{~g}$ apple pomace powder.

$\mathrm{T}_{4}-210 \mathrm{~g}$ wheat flour, $22.5 \mathrm{~g}$ soya bean flour, $22.5 \mathrm{~g}$ carrot powder, $22.5 \mathrm{~g}$ mushroom flour, and $22.5 \mathrm{~g}$ apple pomace powder.

$\mathrm{T}_{5}$ - $180 \mathrm{~g}$ wheat flour, $30 \mathrm{~g}$ soya bean flour, $30 \mathrm{~g}$ carrot powder, $30 \mathrm{~g}$ mushroom flour, $30 \mathrm{~g}$ apple pomace powder.

$\mathrm{T}_{6}-150 \mathrm{~g}$ wheat flour, $37.5 \mathrm{~g}$ soya bean flour, $37.5 \mathrm{~g}$ carrot powder, $37.5 \mathrm{~g}$ mushroom flour, $37.5 \mathrm{~g}$ apple pomace powder.

\section{Experimental procedure}

Proper mixing of wheat flour with multi-flour in different ratio was carried out properly by hand until the formation of firm dough. The dough was rolled out in a baking tray and cut into round in shape with a noodle making machine.

After cutting, oiling and then steaming was done. The noodles were placed in trays and dry in tray dryer at $60^{\circ} \mathrm{C}$ for 60 minutes. The noodles were kept out from tray dryer and cooled at room temperature.

At last, the cooled noodles were packed into HDPE bags and stored for further studies at room temperature. 
Flow chart for the development of multi-flour noodles

Raw materials
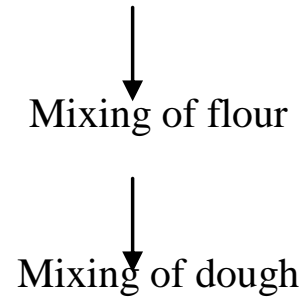

Rolling \& Sheeting
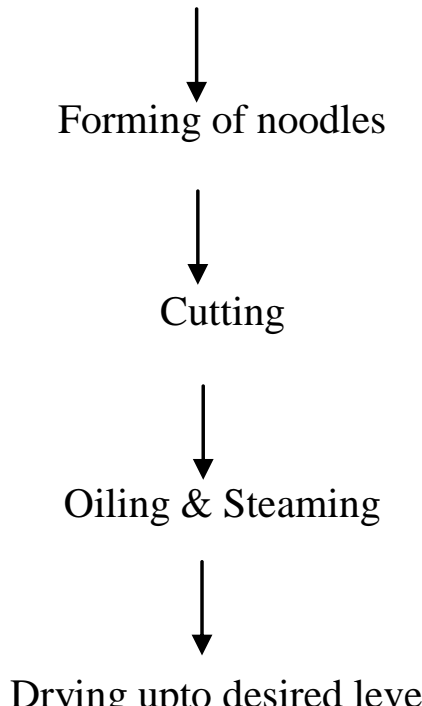

Drying upto desired level

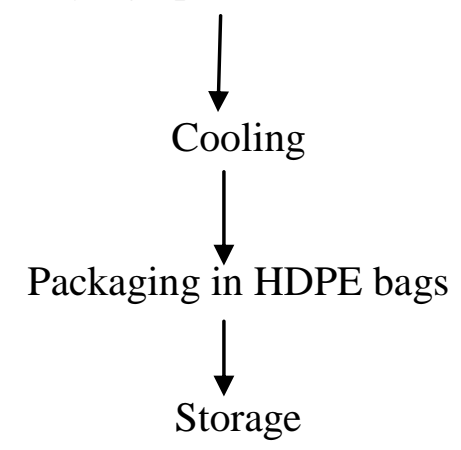

Evaluation of physico-chemical Determination of Minerals (AOAC, 2012) characteristics of noodles

Crude fiber: Crude fiber will be estimated by employing standard method of analysis (AOAC, 1990).

\section{Calculation \\ Concentration $\left(\frac{\mathrm{mg}}{\mathrm{l}}\right)=\frac{(\mathrm{a}-\mathrm{b}) \times \mathrm{v}}{\mathrm{m}}$}

$\begin{array}{ll}\begin{array}{l}\text { Crude fiber } \\ \text { dried weight-ashed weight }\end{array} \text { weight of sample } & (\%)\end{array}=\begin{aligned} & \mathrm{a}=\text { Concentration in test sample solution } \\ & (\mathrm{mg} / \mathrm{kg}) \text { from the graph. } \\ & \mathrm{b}=\text { Concentration in blank solution }(\mathrm{mg} / \mathrm{kg})\end{aligned}$


from the graph.

$\mathrm{v}=$ Final volume make up.

$\mathrm{m}=$ Weight in gm. of test Sample

If test solution is diluted, dilution factor has to be taken in account.

When running replicates, the average of the results should be given with 2 significant figures.

If concentration is in $\mu \mathrm{g} / \mathrm{kg}$ then divide with a factor of 1000 .

\section{Results and Discussion}

The experiments were conducted to develop multi-flours noodles and its physico-chemical quality during storage. Multi- flour comprising wheat flour, soya bean flour, carrot powder, mushroom flour and apple pomace powder were used for the present study. The noodles were formulated using various proportions of flours and other ingredients. All the experiments were conducted in food analysis laboratory and bakery laboratory in the Department of Agricultural Engineering. Multi-flours noodles were packaged in HDPE at room temperature and analyze the physico-chemical characteristics like crude fiber content, iron content and calcium content. The physicochemical characteristics were done as fresh and as well as during storage for 60 days.

\section{Effect on crude fiber}

The data for variation in crude fibre content (\%) of noodles during storage periods are presented in Figure 1. The crude fibre of fresh noodles were observed for noodles $\mathrm{T}_{100}$ (0.85\%), $\quad \mathrm{T}_{90}(1.97 \%), \quad \mathrm{T}_{80}(2.26 \%), \quad \mathrm{T}_{70}$ (2.38\%), $\mathrm{T}_{60}(2.49 \%)$ and $\mathrm{T}_{50}$ noodles (2.65\%). The results revealed the crude fibre content of noodles increased with increase in the incorporation of soy bean, carrot, mushroom and apple pomace powder. Crude fibre content of control noodles was decreased with increasing in storage. Similar trends were also found in other noodles. The study revealed that crude fibre content gradually decreased as increased up to 60 days storage periods under ambient condition.

The crude fibre content of composite flour noodles incorporated soy bean, carrot, mushroom and apple pomace powder with wheat flour were observed highest as compared to control noodles. The highest crude fibre in composite flour noodles due to highest crude fibre content in carrot flour and apple pomace powder as compared to other flour. Similar trends were found by Stojceska et al., (2008) for cereals based ready-to-eat expanded snacks (Fig. 1).

\section{Effect on iron content}

The data for variation in iron content $(\mathrm{mg} / 100 \mathrm{~g})$ of noodles during storage periods are presented in Figure 2. The iron content for fresh noodles was observed 4.54 to $4.90 \mathrm{mg} / 100 \mathrm{gm}$. The content iron was evaluated $(4.90 \mathrm{mg} / 100 \mathrm{gm})$ for $\mathrm{T}_{50}$ noodles followed by $\mathrm{T}_{60} \quad(4.87 \mathrm{mg} / 100 \mathrm{gm}), \quad \mathrm{T}_{70}$ (4.81mg/100gm), $\mathrm{T}_{80}(4.72 \mathrm{mg} / 100 \mathrm{gm}) . \quad \mathrm{T}_{90}$ $(4.63 \mathrm{mg} / 100 \mathrm{gm})$ and $\mathrm{T}_{100}$ noodles $(4.54 \mathrm{mg} / 100 \mathrm{gm})$. The iron content also decreased with increase in the storage period. The iron content value decreased for $T_{100}$ (4.54 to 4.50$), \mathrm{T}_{90}$ (4.63 to 4.57 ), $\mathrm{T}_{80}$ (4.72 to $4.67), \mathrm{T}_{70}(4.81$ to 4.75$), \mathrm{T}_{60}(4.87$ to 4.82$)$ and $\mathrm{T}_{50}(4.90$ to 4.85$)$ up to 60 days of storage periods (Fig. 2).

\section{Effect on calcium content}

The data for variation in calcium content $(\mathrm{mg} / 100 \mathrm{~g})$ of noodles during storage are presented in Figure 3. The calcium content for fresh noodles was observed in the range of 30.15-46.12mg/100g (Fig. 3). 
Fig.1 Effect of multi-flour noodles on crude fiber (\%) during storage period

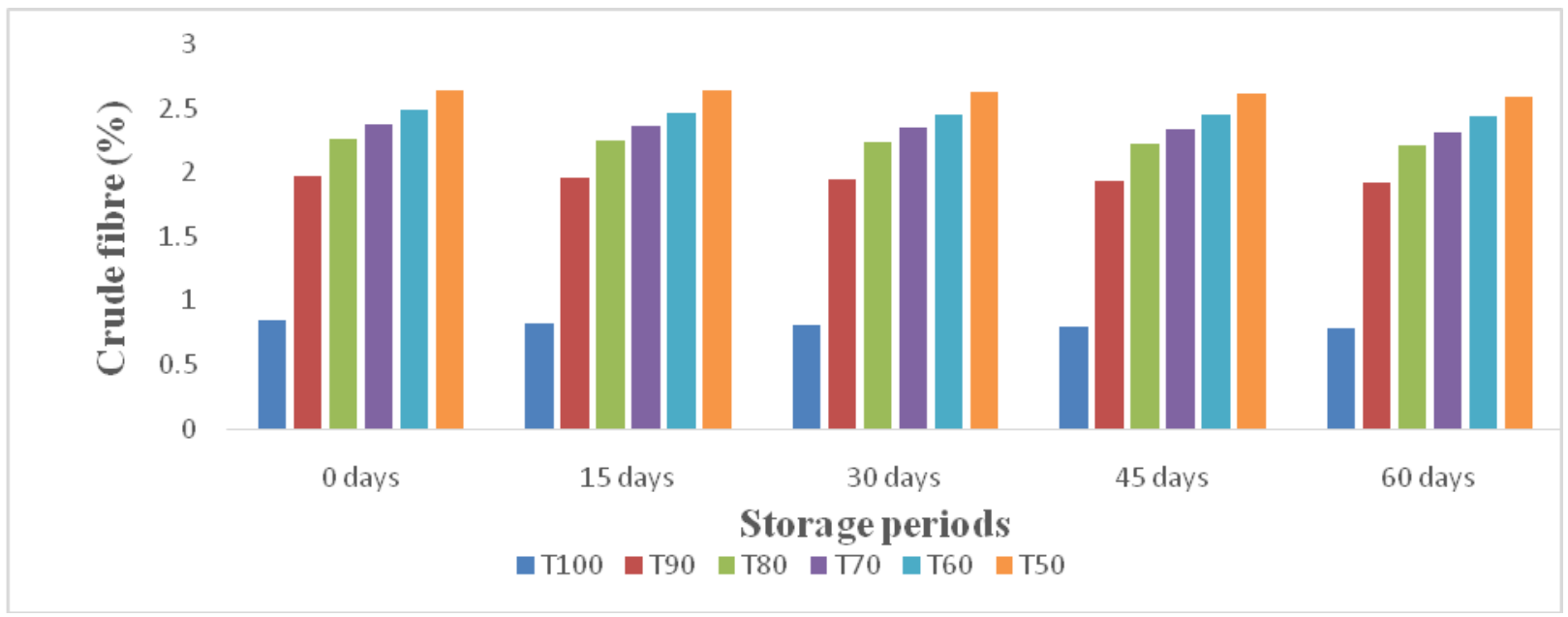

Fig.2 Effect of multi-flour noodles on iron content $(\mathrm{mg} / 100 \mathrm{~g})$ during storage period

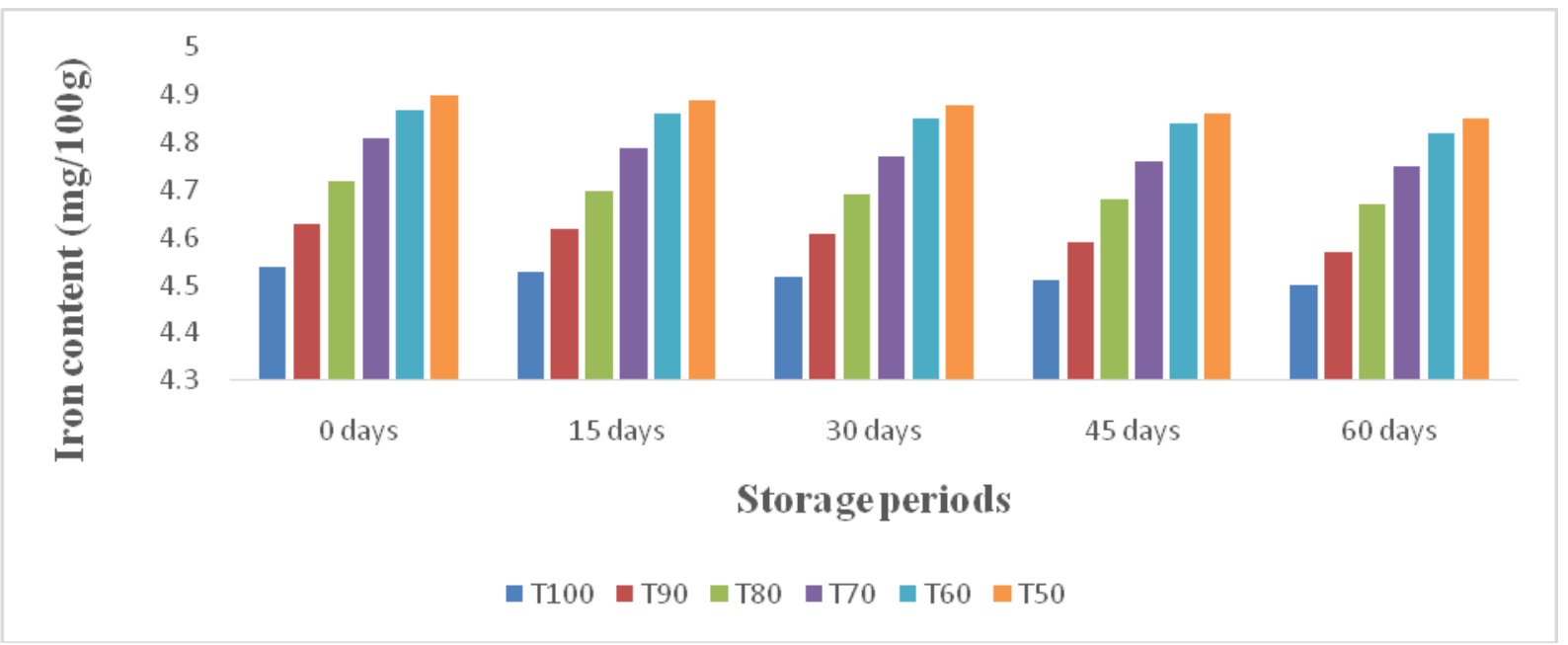

Fig.3 Effect of multi flour noodles on calcium content $(\mathrm{mg} / 100 \mathrm{~g})$ during storage period

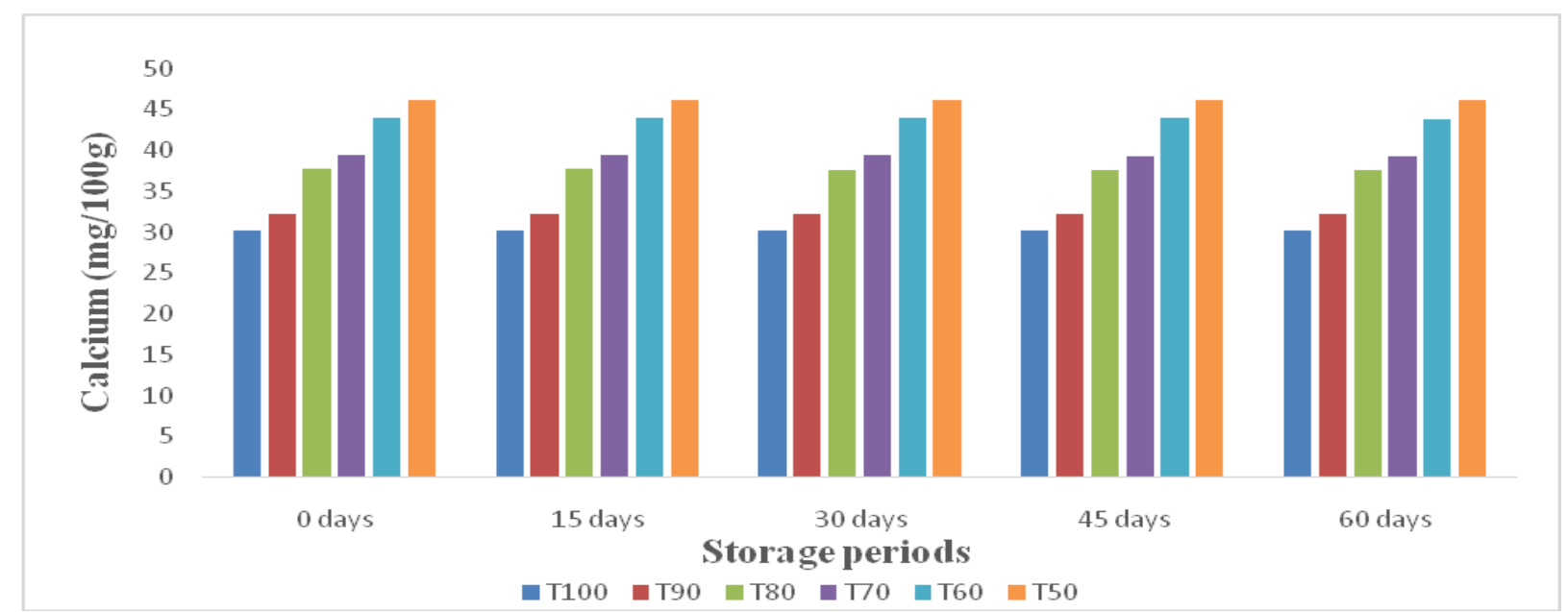


The calcium content was obtain as (46.12mg/100g) for $\mathrm{T}_{50}$ noodles followed by $\mathrm{T}_{60}$ (43.92mg/100g), $\quad \mathrm{T}_{70} \quad(39.34 \mathrm{mg} / 100 \mathrm{~g}), \quad \mathrm{T}_{80}$ $(37.65 \mathrm{mg} / 100 \mathrm{~g}), \quad \mathrm{T}_{90} \quad(32.18 \mathrm{mg} / 100 \mathrm{~g}) \quad$ and control noodles $\mathrm{T}_{100}(30.15 \mathrm{mg} / 100 \mathrm{~g})$. The result of study revealed that the calcium content of noodles increased with increase in the incorporation of soy bean, carrot powder, mushroom and apple pomace powder with wheat flour. The calcium content also decreased with storage period under room condition. The calcium content decreased during storage period for $\mathrm{T}_{100}$ (30.15 to 30.10 ), $\mathrm{T}_{90}$ (32.18 to 32.12 ), $\mathrm{T}_{80}$ (37.65 to 37.59 ), $\mathrm{T}_{70}$ (39.34 to 39.28 ), $\mathrm{T}_{60}$ (43.92 to 43.84 ) and $\mathrm{T}_{50}(46.12$ to 46.08$)$ upto 60 days of storage periods.

In conclusion, incorporation of soy bean flour, carrot powder, mushroom powder and apple pomace powder into wheat flour for the development of noodles is possible based on the physico-chemical properties of the noodles. The results revealed that the incorporated noodles had the highest physico chemical properties during the storage compared to control treatment. Therefore, the treatment $\left(\mathrm{T}_{50}\right)$ has highest physico chemical properties like crude fiber, iron content and calcium content for 60 days stored at room temperature.

\section{References}

Acuna L., Morero, R.D. and Bellomio, A. (2011). Development of Wide-Spectrum Hybrid Bacteriocins for Food Bio-preservation. Food Bioprocess Technol.4:1029-1049.

Ainsworth P., Ibanoglu S., Plunkett A., Ibanoglu E., Stojceska V.,(2007). Effect of brewers spent grain addition and screw speed on the selected physical and nutritional properties of an extruded snack. Journal of Food Engineering, 81, 702-709.
AOAC. (1990). Official methods of analysis. AOAC International suite 500481 North Fredrick Avenue Gaithersburg, Maryland 20877- 2417, USA.

AOAC. (2012). Association of Analytical Communities. 999.11.

Edwards, N.M., Seanlan, M.G., Kruger, J.E., Dexter, J.E. (1996). Oriental noodles dough rheology: Relationship to water absorption, formulation and work input during dough sheeting. Cereal Chem. 73:708-711.

Fabiosa, J.F. (2006). Westernization of the Asian diet-the case of rising wheat consumption in Indonesia. Working paper 06-WP-422, Centre for Agricultural and Rural Development, Iowa State University, Ames, Iowa.

Kumari, S., Grewal, R.B. (2007). Nutritional evaluation and utilization of carrot pomace powder for preparation of high Fiber biscuits. Journal of Food Science \& Technology, 44(1): 56-58.

Sowbhagya, C.M. and Ali, S.Z. (1994). A process for making the noodles from maize. Indian Patent. 1, 83, 077.

Stojceska V., Ainsworth P., Plunkett A., Ibanoğlu S. (2008b). The recycling of brewer's processing by-product into ready-to-eat snacks using extrusion technology. Journal of Cereal Science, 47, 469-479.

Stojceska V., Ainsworth P., Plunkett P., Ibanoglu E., Ibanoglu S. (2008a). Cauliflower byproducts as a new source of dietary fibre, antioxidants and proteins in cereal based ready-to-eat expanded snacks. Journal of Food Engineering, 87, 554-563.

Stojceska, V., Ainsworth, P., Plunkett, A., Ibanoglu, E. and Ibanoglu, S. (2008). Cauliflower by product as a new source dietary fibre, antioxidants and proteins in cereal based ready- to-eat expanded snacks. J. food Eng. vol.87:554-563.

\section{How to cite this article:}

Sunil, Neelesh Chauhan, Vipul Chaudhary, Vaishali, Balwant Singh and Vikrant Kumar. 2019. Effect on Crude Fibre, Iron and Calcium Content of Multi Flour Noodles during Storage. Int.J.Curr.Microbiol.App.Sci. 8(04): 1302-1307. doi: https://doi.org/10.20546/ijcmas.2019.804.150 